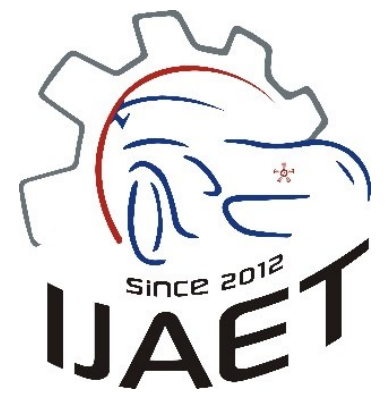

e-ISSN: 2146 - 9067

International Journal of Automotive

Engineering and Technologies

journal homepage: http://ijaet.academicpaper.org

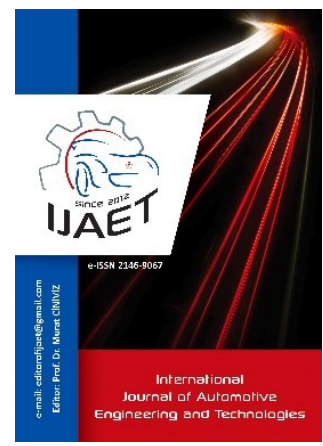

Original Research Article

\title{
Multiparametric engine optimization with application of biodiesel blends for better performance and lower exhaust gas emissions
}

\author{
Ulugbek Azimov ${ }^{1 *}$, Do Hang $\mathrm{Ngu}^{1}$ \\ ${ }^{1}$ University of Northumbria at Newcastle, United Kingdom
}

\author{
ARTICLE INFO \\ * Corresponding author \\ ulugbek.azimov@northumbria.ac.uk \\ Received: February 26, 2018 \\ Accepted: July 13, 2018 \\ Published by Editorial Board \\ Members of IJAET \\ (C) This article is distributed by Turk \\ Journal Park System under the CC \\ 4.0 terms and conditions.
}

\begin{abstract}
In this study the performance and emissions characteristics of 8-cylinder, 4-stroke, turbocharged Ford 6.7L diesel engine operating on conventional diesel fuel, different blends of soybean methyl ester (SME) and pure rapeseed methyl ester (RME) have been modelled. A multiparametric optimization was applied using Rosenbrock's method. It was found that SME B20 was a better choice among other biodiesel blends that showed good emission reduction with little performance differences compared to those of the reference diesel fuel. The optimization analysis allowed achieving $81.8 \%$ reduction in NOx emissions and $75.4 \%$ reduction in the combined $\mathrm{NO}_{\mathrm{x}}$ and $\mathrm{PM}$ emissions.
\end{abstract}

Keywords: Engine performance; Exhaust gas emissions; Biodiesel blends; Multiparametric optimization

\section{Introduction}

Biodiesel is a renewable alternative fuel that can be used in diesel engines with little engine modifications. It can be produced from vegetable oils and animal fats including waste cooking oils through a transesterification process which separates glycerine from fat or oil and left methyl ester behind. Although diesel engines have higher efficiency than other engines used in transport, they are also heavy air pollutants. In conventional diesel combustion air pollutants are very difficult to control due to a soot- $\mathrm{NO}_{\mathrm{x}}$ trade-off, so a reduction in one contaminant usually results in an increase in another. To reduce pollution level from diesel engines different types of biofuels have been used. Many researchers have investigated the performance and emission characteristics of diesel engines with biodiesel fuel produced from different feedstock. Özener et al. [1] studied the effect of blending of soybean methyl ester biodiesel on the performance, emissions and combustion characteristics of a diesel engine. They tested $10 \%, 20 \%, 50 \%$ and $100 \%$ biodiesel blends. The torque decreased and the brake specific fuel consumption increased with an increase in the biodiesel blend ratio. Also the increased nitrogen oxides (NOx) and carbon dioxide (CO2) emissions, and reduced carbon monoxide $(\mathrm{CO})$ and unburned total hydrocarbon (THC) emissions were observed. It was shown that the biodiesel blends and pure biodiesel have a shorter ignition delays compared to the diesel fuel. Celikten et al. [2] conducted experiments 
on a 4-cylinder diesel engine with three different tested fuels: diesel fuel, pure RME and pure SME biodiesel at different injection pressures of 250 bar, 300 bar, 350 bar. It was found that for all tested fuels, the engine torque and power decreased as injection pressure increased. Also smoke level and carbon monoxide (CO) emissions decreased but nitrogen oxides (NOx) emissions increased. For engine performance, combustion with soybean biodiesel showed the lowest level followed by rapeseed biodiesel and the diesel fuel showed the highest value. It was found that combustion with biodiesel had higher NOx emission than those of diesel fuel but had lower smoke level and $\mathrm{CO}$ emission levels for all injection pressures. NOx emission level can be controlled by using exhaust gas recirculation (EGR) system by reducing in-cylinder temperature. Palash et al. [3] mentioned that EGR is the most effective method for reducing NOx emission. It decreases about $25-75 \%$ of NOx emission with biodiesel at 5-25\% EGR rate. EGR also reduces $\mathrm{HC}$ and $\mathrm{CO}$ emissions slightly, but it increases the brake specific fuel consumption and smoke emissions.

Although researchers have conducted many experiments with biodiesel fuels and compared the engine performance and emissions characteristics, none of them suggested how the engine design or operating parameters could be improved to achieve high performance and low emissions. In the present study, a computational modelling and multiparametric optimization have been conducted to analyze the performance and emissions characteristics of a commercial diesel engine fuelled with soybean methyl ester (SME) and rapeseed methyl ester (RME) and the optimum engine design and operation parameters were suggested to achieve optimum engine performance with biodiesel combustion.

\section{Theory and Modeling}

In this study we have used full cycle thermodynamic engine simulation programme Diesel-RK. The program can be used for modelling direct injection diesel engines, spark ignition petrol/gas engines, dual fuel engines, opposed piston engine and etc. The typical applications include engine performance predictions, analysis and optimization of combustion, emissions, valve timing, EGR system, turbocharger, fuel injection system and piston bowl shape, and conversion of diesel engine into gas engine. Several numerical analysis of engine operation and optimization have been applied using Diesel-RK software [48]. Diesel-RK has a fuel spray visualization tool, multiparametric and multidimensional optimization tool and 1D \& 2D parametric procedures. The program includes RK-model that is a multi-zone diesel fuel spray mixture formation and combustion model, which takes into account:

- Piston bowl shape - any geometrical shapes can be specified and saved,

- Different swirl profiles and swirl intensity,

- Injector location - central, non-central, side injection, few injectors,

- Number, diameter and direction of injector nozzles,

- Fuel properties, including biofuels and blends of biofuels with diesel oil,

Shape of injection profile including multiple injections.

\subsection{Multiparametric Optimization}

As mentioned earlier, multiparametric optimization is one of the advanced features in Diesel-RK [9]. The procedure of optimization uses the engine's mathematical model together with the specified goal function and restrictions to find a set of optimal design parameters.

\section{Goal function}

The efficiency parameters of an engine or its separate processes can be included in a goal [10]:

$$
Z_{j}=Z_{j}\left(X_{k}\right)
$$

where:

$Z_{j}$ is a function of several variables.

Since the main aim of this study was to reduce the exhaust gas emissions in biodiesel fuelled engine the goal function for the optimization was set as a complex emission parameter Summary of Emissions (SE). It is stated that the complex of air pollutants is a sum of particulate matter (PM) and nitrogen oxide $\left(\mathrm{NO}_{\mathrm{x}}\right)$ emissions and can be calculated as:

$S E=C_{P M} \frac{P M}{0.15}+C_{N O} \frac{N O_{x}}{7}$

where:

$C_{P M}=0.5$, is the empiric line factor for Particulate Matter emission. 
$C_{N O}=1$, is the empiric line factor for Nitrogen

Oxides emission

Independent variables

The set of design engine parameters form the vector of independent variables, $X_{k}$ and it is in the restricted solutions area [10]:

$X_{k \min }<X_{k}<X_{k \max }$

In this study, there are six engine parameters selected as the variables for the optimization:

- $X_{1}$ is intake and exhaust valve timing (opening/closing),

- $X_{2}$ is compression ratio,

- $X_{3}$ is injector nozzle diameter,

- $X_{4}$ is injection timing,

- $X_{5}$ is injection duration,

- $X_{6}$ is EGR rate.

With these variables, the goal function becomes: $Z_{j}=Z_{j}\left(X_{1}, X_{2}, X_{3}, X_{4}, X_{5}, X_{6}\right)$

\section{Restrictions}

Restrictions are the parameters that limit the optimal search region while searching the solution in the pool of engine parameters:
$Y_{i}=Y_{i}\left(X_{k}\right)$

For example, in this case the restricting parameters will be: $Y_{1}$ is power, $Y_{2}$ is specific fuel consumption (SFC) and $Y_{3}$ is volumetric efficiency. To search for an optimum of function $Z_{j}\left(X_{k}\right)$, the following restrictions have to be fulfilled [10]:

$Y_{i \min }<Y_{i}\left(X_{k}\right)<Y_{i \max }$

Generally, the goal function is a sum of $Z_{j}, X_{k}$ and $Y_{i}[4]$ :

$$
\mathrm{F}=\mathrm{C}_{\mathrm{z} j} \cdot \overline{\mathrm{Z}}_{\mathrm{j}}+\sum_{\mathrm{i}=1}^{\mathrm{n}}\left(\mathrm{C}_{\mathrm{yi}} \cdot \Delta \overline{\mathrm{Y}}_{\mathrm{i}}^{2}\right)+\sum_{\mathrm{k}=1}^{\mathrm{m}}\left(\mathrm{C}_{\mathrm{xk}} \cdot \Delta \overline{\mathrm{X}}_{\mathrm{k}}^{2}\right)
$$

where:

$C_{z j}$ is a line factor (influence coefficient) of optimized ICE parameter $Z_{j}$ included into goal function; $\bar{Z}_{j}=Z_{j} / Z_{j \text { mean }}$ is a relative ICE parameter $Z_{j}$ related to its mean average value (e.g. Power, SFC, NOx emission, etc.); $C_{y i}$ is a penalty factor for leaving permitted area of $Y_{i}$;

$$
\Delta \bar{Y}_{i}=\left\{\begin{array}{lc}
\frac{Y_{i}-Y_{i \min }}{Y_{i \text { mean }}}, & I F Y_{i}<Y_{i \min } \\
0, & I F Y_{i \min } \leq Y_{i} \leq Y_{i \max } \\
\frac{Y_{i}-Y_{i \max }}{Y_{i \text { mean }}}, & I F Y_{i}>Y_{i \max }
\end{array}\right\} \text { is a related value of } Y_{i} ;
$$

$C_{x k}$ is a penalty factor for leaving permitted area of $X_{k}$;

$$
\Delta \bar{X}_{k}=\left\{\begin{array}{lc}
\frac{X_{k}-X_{k \min }}{X_{k \text { mean }}}, & \text { IF } X_{k}<X_{k \min } \\
0, & \text { IF } X_{k \min } \leq X_{k} \leq X_{k \max } \\
\frac{X_{k}-X_{k \text { max }}}{X_{k \text { mean }}}, & \text { IF } X_{k}>X_{k \max }
\end{array}\right\} \text { is a related value of } X_{k}
$$

Mean values of explanatory variables $X_{k \text { mean }}$ and restrictions $Y_{i \text { mean }}$ as well as penalty factors of $X_{k}$ are set by the program. Specification of penalty factors for restrictions $C_{y i}$; maximum and minimum borders for restrictions $Y_{i \mathrm{~min}}$, $Y_{i \max }$ and explanatory variables $X_{i \min }, X_{i \max }$ as well as goal function $Z_{j}$ has to be made by user in the pre-processor of the program [10].

\section{Algorithm Selection}

Unfortunately, the theory of nonlinear programming does not answer the question which method is better to solve the multiparametric optimization problem and a researcher has to be guided by his/her own experience of solving problem while selecting optimization algorithm. Each algorithm allows finding solutions of optimization problems with different efficiency. For example, Monte-Carlo method is preferred to be used when the optimization problem is posed with a large number of independent variables and it is advisable to set a large number of iterations up to 1000 . Due to the restricted power, specific fuel consumption and volumetric efficiency set in this case, the expected optimum will not be 
far from the starting point, and hence a zeroorder optimization method was used. It is advised that the first-order method be used in the case when expected optimum is far from the starting point.

As categorized under zero-order methods - oncoordinates descent method, deformable polyhedron method, Powell method and Rosenbrock's method, these four methods were used to perform multiparametric optimization. The deformable polyhedron method failed to find a local optimum, it did not converge and hence caused errors during optimization process. On-coordinates descent method and the Powell method were not preferred because the optimization results showed the exceeding values for restricted parameters. Rosenbrock's method was the only method that provided optimization results by keeping the parameters within the restricted range. Rosenbrock's method [11] proceeds by a series of stages and each stage consists of a number of exploratory searches along a set of directions. The directions are fixed for the given stage and updated from stage to stage for the make use of information obtained about the objective. In the first stage, Rosenbrock's method starts with the search of coordinate directions. It conducts searches of the directions by cycling over each in turn and then moving to new iterations that produce successful steps. The process continues until there has been at least one successful and one unsuccessful step in each search direction, and the current stage terminates after that. For the next stage, Rosenbrock's rotates the set of directions instead of repeating the search process at the same orthogonal vectors, to seize information about the objective validated during the early course of action. Rosenbrock's method imposes the condition that the set of search directions always be $n$ dimensional so that the set of vectors remains independent. The function is defined as:

$$
f(x, y)=(a-x)^{2}+b\left(y-x^{2}\right)^{2}
$$

\subsection{Computational Setup}

In order to perform simulation and multiparametric optimization of an engine, the engine parameters and the properties of fuels have to be specified. In this study, Ford 6.7L V8 four stroke, turbocharged, DI diesel engine was used as a reference engine for the conversion with biodiesel application. The specifications of engine are listed in Table 1 [12].

\begin{tabular}{ll} 
& Table 1. Engine specification \\
\hline Engine Model & Ford Power Stroke V-8 4-stroke DI diesel engine \\
No. of Cylinders & 8 \\
Bore x Stroke & $99 \mathrm{~mm} \times 108 \mathrm{~mm}$ \\
Displacement & 6.7 liters \\
Compression Ratio & $16.2: 1$ \\
Injection Pressure & $2000 \mathrm{bar}$ high pressure, Common Rail \\
Injection Nozzle & $19 \mathrm{~mm}$ piezo actuated injectors with 8 holes \\
Maximum Power & $223 \mathrm{~kW} @ 2800 \mathrm{rpm}$ \\
Maximum Torque & $894 \mathrm{Nm} @ 1600 \mathrm{rpm}$ \\
Valve Timings IVO/IVC $\left({ }^{\circ} \mathrm{CA}\right)$ & $15 \mathrm{bTDC} / 40 \mathrm{aBDC}$ \\
\multicolumn{1}{c}{ EVO/EVC $\left({ }^{\circ} \mathrm{CA}\right)$} & $60 \mathrm{bBDC} / 15 \mathrm{aTDC}$ \\
\hline
\end{tabular}

Table 2. Fuel properties

\begin{tabular}{lccccc}
\hline \multirow{2}{*}{ Property } & Diesel No. & SME & SME & SME & RME \\
& 2 & B20 & B40 & B100 & B100 \\
\hline C mass fraction & 87 & 84.96 & 82.97 & 77.31 & 78 \\
H mass fraction & 12.6 & 12.45 & 12.3 & 11.88 & 13.5 \\
O mass fraction & 0.4 & 2.591 & 4.73 & 10.81 & 8.5 \\
Density @ 323K $\left(\mathrm{kg} / \mathrm{m}^{3}\right)$ & 830 & 841 & 852 & 885 & 874 \\
Viscosity @ 323K $(\mathrm{Pa} . \mathrm{s})$ & 0.003 & 0.003343 & 0.003677 & 0.00463 & 0.00692 \\
Low heating value $(\mathrm{MJ} / \mathrm{kg})$ & 42.5 & 41.18 & 39.89 & 36.22 & 37.1 \\
Cetane number & 48 & 48.68 & 49.37 & 51.3 & 39 \\
Specific heat of vaporization $(\mathrm{kJ} / \mathrm{kg})$ & 250 & 265.8 & 281.2 & 325 & 325 \\
\hline
\end{tabular}

\section{Results and Discussion}

The simulations were conducted using diesel fuel first in order to obtain the reference values for further comparison of engine performance characteristics with other simulated fuels such as SME B20, SME B40, SME B100 and RME 
B100. Under the same engine conditions, the diesel fuel was replaced by other simulated fuels and the results are shown in Figures 1 and 2 . Figure 1 illustrates the variation of engine power with a range of engine speed for all simulated fuels and Figure 2 shows the brake torque of the engine using all simulated fuels. It can be seen that SME B20 has the best performance among all biodiesel blends. However, the peak power at $2800 \mathrm{rpm}$ decreased about $23 \%$ for SME B100 and the peak torque at $1600 \mathrm{rpm}$ decreased about $16 \%$ for the same fuel compared to the reference diesel fuel.

The engine is designed in such a way that it is most efficient between 1600 RPM, as shown in Figure 2, and 2800 RPM, as shown in Figure 1. That means that the valve timing and camshaft profiles were made in such a way that the engine "breathes" best between those speeds. That's why the torque is maximum in that region. Another thing is that as the rpm increases, it gets harder and harder to get the optimal amount of air and fuel into the cylinder and burn it at the optimal rate. The faster the engine revolutions, the less time there is to suck in, compress, burn and blow out. Hence, the engine power and torque decrease after the relevant rpms.

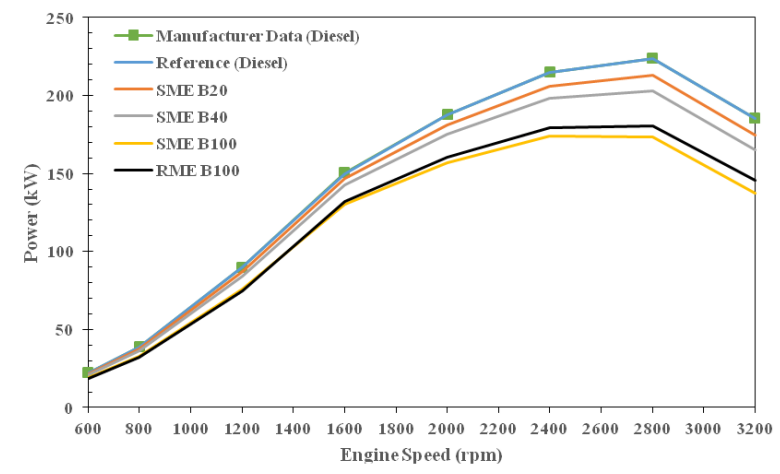

Figure 1. Variation of engine power with a range of engine speed

Figure 3 shows the brake specific fuel consumption for the simulated fuels. The brake specific fuel consumption is a ratio of the engine fuel consumption and the engine power. It measures how efficiently an engine is using the fuel supplied to produce work. It is found that the brake specific fuel consumption increases with the increasing percentage of biodiesel blends. The same trend was obtained by most of the researches [14-17]. The increase in brake specific fuel consumption with biodiesel fuels is due to the combined effects of the higher fuel density and lower heating value. The higher density of biodiesel has led to more fuel being injected for the same injection pressure, thereby increasing the specific fuel consumption [18]. The lower heating value of biodiesel will require more fuel to be injected into the combustion chamber to maintain a constant power output [19]. Xue [18] reviewed that the fuel consumption becomes higher when the engine is fueled with biodiesel because it is required to compensate the loss of heating value of biodiesel. Figure 3 shows that in the engine rpm range between $1600 \mathrm{rpm}$ (max. torque) and 2800 rpm (max. power) the maximum specific fuel consumption for SME B100 at $1600 \mathrm{rpm}$ it showed about $13 \%$ increase and at $2800 \mathrm{rpm}$ it showed about $32 \%$ increase compared to the reference diesel fuel. This trend is consistent as the density of SME B100 is the highest among other biodiesel blends used in this study, as shown in Table 2.

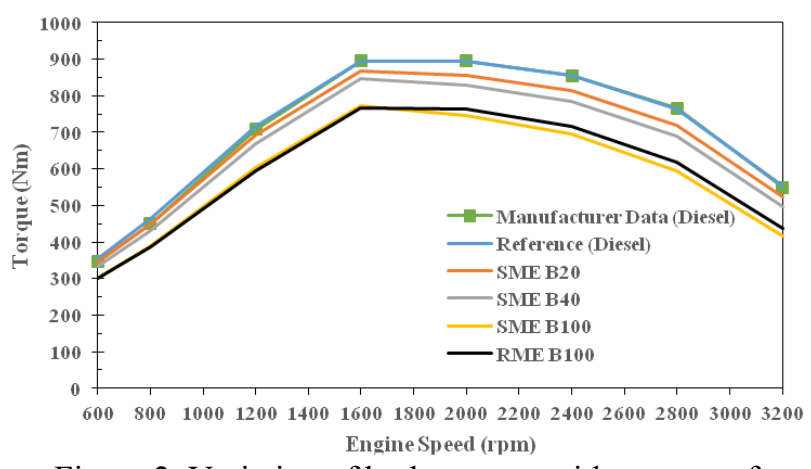

Figure 2. Variation of brake torque with a range of engine speed

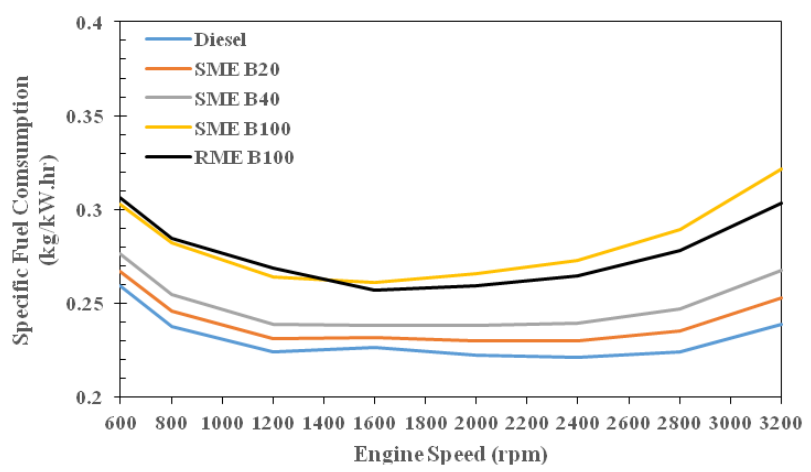

Figure 3. Variation of brake specific fuel consumption with a range of engine speed

Figure 4 shows the heat release rate for simulated fuels. It was shown that diesel fuel has the highest peak of heat release rate and the combustion process is slightly advanced for SME B20 and B40 compared to diesel fuel. Although it is difficult to estimate the rate of change of the heat release for different biodiesel 
blends due to the transient nature of the heat release affected by the mixing and combustion of fuels with different physical properties, we can at least estimate the pick of the heat release in the diffusion combustion zone. As shown in Figure 4 , the pick of heat release at $370 \mathrm{CA}$ degree for RME B100 decreased about 20\% compared to the reference diesel fuel.

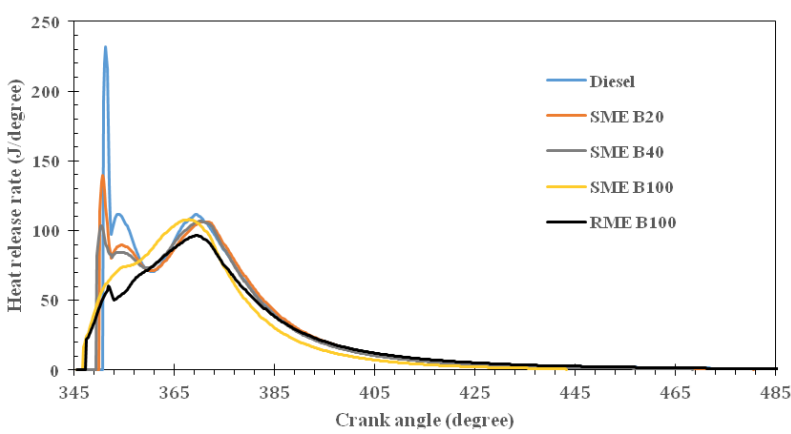

Figure 4. Variation of heat release rate at max. torque at $1600 \mathrm{rpm}$

Figure 5 illustrates the variation of average cylinder temperature with crank angle for the simulated fuels. It shows that the biodiesel has lower cylinder temperature compared to that of diesel fuel. The lower cylinder temperature occurs with the increase of biodiesel percentage in the fuel blend. It was found that the maximum in-cylinder temperature for RME B100 was $10 \%$ lower than that of diesel reference fuel and in-cylinder temperatures for other biodiesel blends were between these limits.

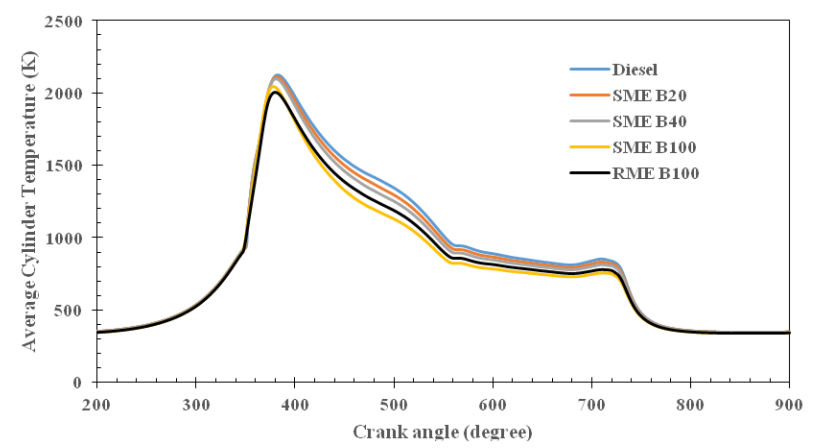

Figure 5. Variation of average cylinder temperature at max. torque at $1600 \mathrm{rpm}$

Figure 6 shows the $\mathrm{NO}_{\mathrm{x}}$ emission for the simulated fuels. The $\mathrm{NO}_{\mathrm{x}}$ emission for each biodiesel is higher than that for diesel fuel. Higher $\mathrm{NO}_{\mathrm{x}}$ emission was occurred with the increased percentage of biodiesel in the blend. The biodiesel molecule contains oxygen to react with the nitrogen resulting in a higher amount of $\mathrm{NO}_{\mathrm{x}}$ formation [20].

Figure 7 shows the PM emission for the simulated fuels. The soybean biodiesel SME provides positive impact on PM emission. The same trends were previously obtained by Nabi [16] and Borgelt [20].

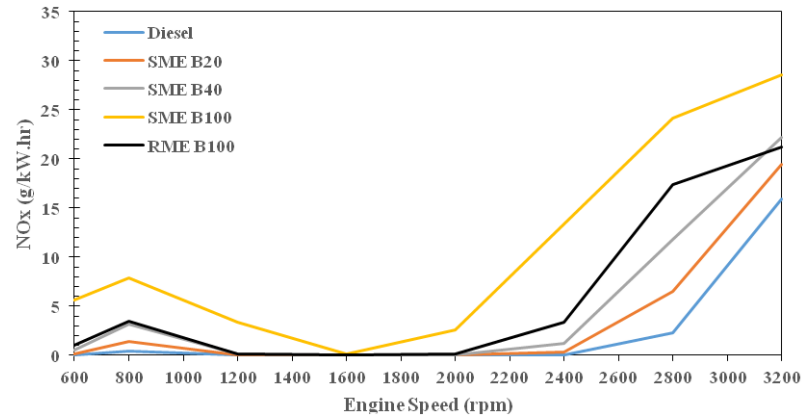

Figure 6. Variation of $\mathrm{NO}_{\mathrm{x}}$ at different engine speed

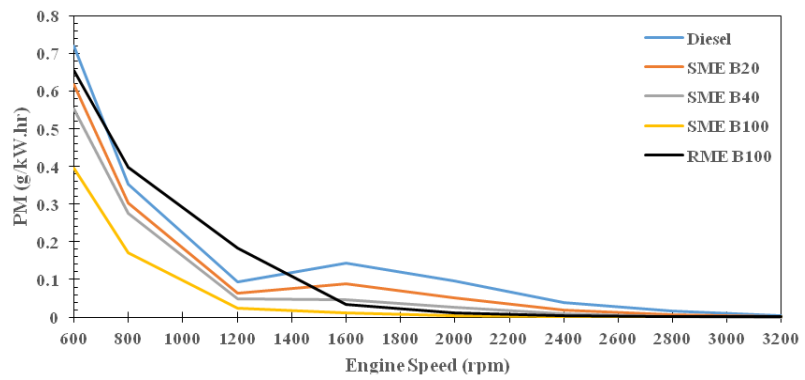

Figure 7. Variation of PM with a range of engine speed

\subsection{Multiparametric Optimization}

Rosenbrock's method was used for engine multidimensional optimization to find out the optimum variables such as intake and exhaust valve timing (opening/closing), compression ratio, injection timing, injection duration, injector nozzle diameter and exhaust gas recirculation ratio in order to achieve the lowest emissions and specific fuel consumption levels.

\section{Intake and exhaust valve timing}

During optimization analysis, it was found that the optimized values of the intake and exhaust valve opening/closing timings were different for every rpm. Since the investigated engine did not have variable valve timing mechanism, the valve opening/closing timing were set as: intake valve opening - $15^{\circ} \mathrm{bTDC}$, intake valve closing $-40^{\circ} \mathrm{aBDC}$, exhaust valve opening $-60^{\circ} \mathrm{bBDC}$ and exhaust valve closing $-15^{\circ}$ aTDC.

\section{Compression ratio}

Table 3 shows the engine optimization results for the compression ratio at different engine speeds. It can be seen that compression ratio 15.7 at $1600 \mathrm{rpm}$ and $2800 \mathrm{rpm}$ has the lowest summary emissions. Although $600 \mathrm{rpm}$ has the lowest summary emissions at compression ratio 17.2, it has lower volumetric efficiency. In 
addition, the compression ratio has to be constant for all rpm therefore by considering all the results at each rpm, compression ratio 16.2 was used as the final optimization parameter.

Table 3. Optimization results for compression ratio

\begin{tabular}{|c|c|c|c|c|}
\hline \multicolumn{5}{|c|}{$600 \mathrm{rpm}$ (Idling) } \\
\hline & Power $(\mathrm{kW})$ & $\begin{array}{c}\text { Specific Fuel } \\
\text { Consumption } \\
(\mathrm{kg} / \mathrm{kW} . \mathrm{hr})\end{array}$ & $\begin{array}{l}\text { Volumetric } \\
\text { Efficiency }\end{array}$ & $\begin{array}{l}\text { Summary } \\
\text { Emissions } \\
\text { (g/kW.hr) }\end{array}$ \\
\hline 16.2 CR (Base line) & 21.629 & 0.26631 & 0.92147 & 1.8736 \\
\hline 15.7 CR (Optimized) & 21.612 & 0.26652 & 0.9216 & 1.8853 \\
\hline 17.2 CR (Optimized) & 21.615 & 0.26648 & 0.917 & 1.8269 \\
\hline \multicolumn{5}{|c|}{$1600 \mathrm{rpm}$ (Maximum Torque) } \\
\hline & Power (kW) & $\begin{array}{c}\text { Specific Fuel } \\
\text { Consumption } \\
(\mathrm{kg} / \mathrm{kW} . \mathrm{hr})\end{array}$ & $\begin{array}{l}\text { Volumetric } \\
\text { Efficiency }\end{array}$ & $\begin{array}{l}\text { Summary } \\
\text { Emissions } \\
\text { (g/kW.hr) } \\
\end{array}$ \\
\hline 16.2 CR (Base line) & 146.97 & 0.23149 & 0.92344 & 0.27334 \\
\hline 15.7 CR (Optimized) & 146.74 & 0.23186 & 0.92477 & 0.26313 \\
\hline 17.2 CR (Optimized) & 147.33 & 0.23092 & 0.92004 & 0.28913 \\
\hline \multicolumn{5}{|c|}{2800 rpm (Maximum Power) } \\
\hline & Power (kW) & $\begin{array}{c}\text { Specific Fuel } \\
\text { Consumption } \\
(\mathrm{kg} / \mathrm{kW} . \mathrm{hr})\end{array}$ & $\begin{array}{l}\text { Volumetric } \\
\text { Efficiency }\end{array}$ & $\begin{array}{l}\text { Summary } \\
\text { Emissions } \\
\text { (g/kW.hr) }\end{array}$ \\
\hline 16.2 CR (Base line) & 214.06 & 0.2345 & 0.94669 & 0.88801 \\
\hline 15.7 CR (Optimized) & 213.94 & 0.23464 & 0.94849 & 0.8631 \\
\hline 17.2 CR (Optimized) & 213.65 & 0.23495 & 0.94221 & 0.92745 \\
\hline
\end{tabular}

Table 4. Optimization results for injector nozzle diameter.

\begin{tabular}{|c|c|c|c|c|}
\hline \multicolumn{5}{|c|}{600 rpm (Idling) } \\
\hline & Power $(\mathrm{kW})$ & $\begin{array}{c}\text { Specific Fuel } \\
\text { Consumption } \\
(\mathrm{kg} / \mathrm{kW} . \mathrm{hr})\end{array}$ & $\begin{array}{l}\text { Volumetric } \\
\text { Efficiency }\end{array}$ & $\begin{array}{l}\text { Summary } \\
\text { Emissions } \\
(\mathrm{g} / \mathrm{kW} . \mathrm{hr}) \\
\end{array}$ \\
\hline $0.19 \mathrm{~mm}$ (Base line) & 21.650 & 0.26605 & 0.92116 & 1.8731 \\
\hline $0.18 \mathrm{~mm}$ (Optimized) & 21.701 & 0.26542 & 0.91803 & 1.6342 \\
\hline \multicolumn{5}{|c|}{1600 rpm (Maximum Torque) } \\
\hline & Power $(\mathrm{kW})$ & $\begin{array}{c}\text { Specific Fuel } \\
\text { Consumption } \\
\text { (kg/kW.hr) }\end{array}$ & $\begin{array}{l}\text { Volumetric } \\
\text { Efficiency }\end{array}$ & $\begin{array}{l}\text { Summary } \\
\text { Emissions } \\
\text { (g/kW.hr) } \\
\end{array}$ \\
\hline 0.19 mm (Base line) & 146.99 & 0.23147 & 0.92330 & 0.27356 \\
\hline $0.18 \mathrm{~mm}$ (Optimized) & 146.87 & 0.23164 & 0.92350 & 0.27868 \\
\hline \multicolumn{5}{|c|}{2800 rpm (Maximum Power) } \\
\hline & Power $(\mathrm{kW})$ & $\begin{array}{c}\text { Specific Fuel } \\
\text { Consumption } \\
\text { (kg/kW.hr) }\end{array}$ & $\begin{array}{l}\text { Volumetric } \\
\text { Efficiency }\end{array}$ & $\begin{array}{l}\text { Summary } \\
\text { Emissions } \\
\text { (g/kW.hr) }\end{array}$ \\
\hline $0.19 \mathrm{~mm}$ (Base line) & 214.05 & 0.23452 & 0.94648 & 0.88573 \\
\hline $0.18 \mathrm{~mm}$ (Optimized) & 214.02 & 0.23455 & 0.94684 & 0.88714 \\
\hline
\end{tabular}

\section{Injector nozzle diameter}

The correlation between a nozzle diameter and a cylinder diameter is presented in Diesel-RK and it was stated that for perspective high-speed diesel engines with cylinder bore less than 150 $\mathrm{mm}$, the nozzle diameter can be reduced by 0.1 to $0.15 \mathrm{~mm}$. Since the diameter of cylinder of Ford diesel V-8 engine is only $99 \mathrm{~mm}$, and after the deduction, the minimum nozzle diameter in this case will be $0.15 \mathrm{~mm}$ and maximum nozzle diameter will be $0.19 \mathrm{~mm}$. Those values were used as the solution definition range in the multiparametric optimization. Table 4 shows the optimization results for injector nozzle diameters. It can be observed that the best emission reduction occurs with the $0.19 \mathrm{~mm}$ nozzle diameter.

\section{Injection timing and injection duration}

Al-Dawody and Bhatti [21] mentioned that the most reduction in $\mathrm{NO}_{\mathrm{x}}$ emission with biodiesel 
fuel can be achieved by retarding the injection timing and increasing the nozzle diameter. The results of optimized injection timing and duration are recorded and listed in Table 5. At
$2800 \mathrm{rpm}$, the injection timing retarded from $24.5^{\circ} \mathrm{CA}$ to $23^{\circ} \mathrm{CA}$ has reduced the NOx and SE emissions by $6.2 \%$ and $5.8 \%$ respectively.

Table 5. Comparison of baseline and optimized injection timing and duration

\begin{tabular}{ccccc}
\hline \multirow{2}{*}{ Engine Speed } & \multicolumn{2}{c}{$\begin{array}{c}\text { Injection Timing } \\
\text { (degree bTDC) }\end{array}$} & \multicolumn{2}{c}{$\begin{array}{c}\text { Injection Duration } \\
\text { (crank angle) }\end{array}$} \\
\cline { 2 - 5 } & Base line & Optimized & Base line & Optimized \\
\hline $600 \mathrm{rpm}$ & 6 & 6 & 22 & 20.5 \\
$800 \mathrm{rpm}$ & 7.5 & 7.5 & 23 & 21.5 \\
$1200 \mathrm{rpm}$ & 11 & 11 & 25 & 23.5 \\
$1600 \mathrm{rpm}$ & 14.5 & 14.5 & 22 & 25 \\
$2000 \mathrm{rpm}$ & 18 & 18 & 17 & 20 \\
$2400 \mathrm{rpm}$ & 21 & 19.5 & 16 & 16 \\
$2800 \mathrm{rpm}$ & 24.5 & 23 & 16 & 16 \\
$3200 \mathrm{rpm}$ & 25 & 23.5 & 15 & 15 \\
\hline
\end{tabular}

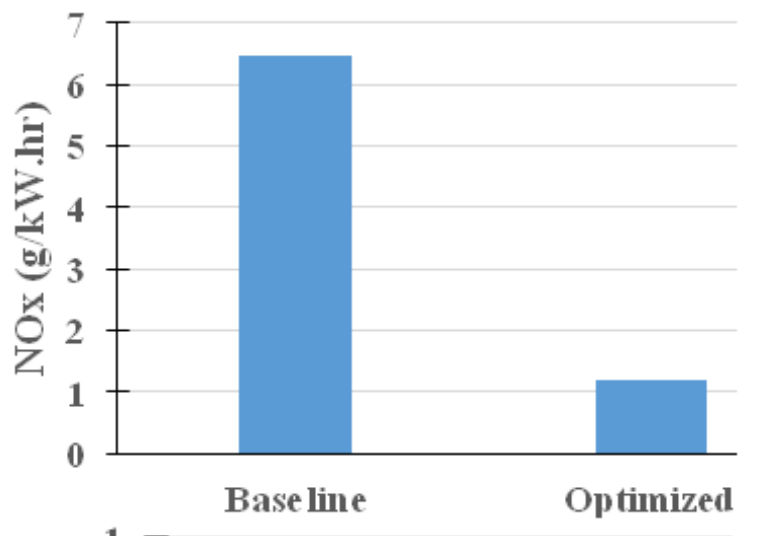

reduction in $\mathrm{NO}_{\mathrm{x}}$ and summary emissions with the increase of EGR ratio from 0 to 0.004 . Figure 8 shows the optimized emissions results at $2800 \mathrm{rpm}$ with the SME B20 biodiesel. Figure 9 shows the comparison of brake specific fuel consumption of SME B20 before and after the optimization.

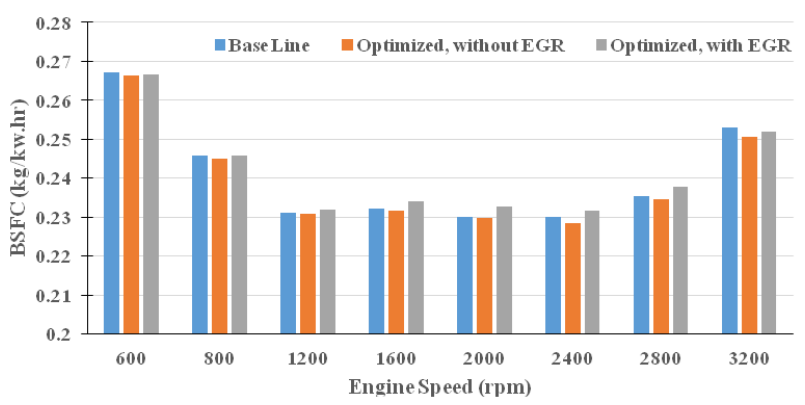

Figure 9. Comparison of optimized BSFC for SME B20 at different engine speed

Therefore, using Rosenbrock's optimization method it was possible to achieve $81.8 \%$ reduction in the $\mathrm{NO}_{\mathrm{x}}$ emission and $75.4 \%$ reduction in the Summary Emissions (SE) compared to those of the baseline for SME B20 at $2800 \mathrm{rpm}$ with compression ratio-16.2, nozzle diameter-0.19 $\mathrm{mm}$, injection timing- $23^{\circ} \mathrm{bTDC}$, injection duration-16 $\mathrm{CA}^{\circ}$ and EGR ratio-0.004.

\subsection{Piston Bowl Analysis}

Table 5 shows the engine performance and emissions results at $2800 \mathrm{rpm}$ with different types of piston bowls. Kuleshov [22] stated that deep piston bowls are preferable for low boosting pressure engines with a small cylinder bore due to a longer spray tip penetration. However, if the BMEP is high, the deeper piston bowl geometry causes excessive overlap of 
near-wall flow zones formed by adjacent sprays leading to the reduction of the engine performance. As shown in Table 5, the Mexican hat is the preferred piston bowl with better engine performance compared to the baseline piston bowl configuration with the deepest bowl geometry. Although the $\mathrm{NO}_{\mathrm{x}}$ emission from Mexican hat increases compared to that of the base line, the PM emission significantly decreases, and hence, it causes a reduction in summary emissions (SE).

\begin{tabular}{|c|c|c|c|c|c|c|c|c|}
\hline $\begin{array}{l}\text { Type of } \\
\text { Piston Bowl }\end{array}$ & $\begin{array}{l}\text { Bowl Diameter } \\
(\mathrm{mm})\end{array}$ & $\begin{array}{l}\text { Bowl Depth } \\
\text { (mm) }\end{array}$ & $\begin{array}{l}\text { Power } \\
(\mathrm{kW})\end{array}$ & $\begin{array}{l}\text { Torque } \\
(\mathrm{Nm})\end{array}$ & $\begin{array}{c}\mathrm{SFC} \\
(\mathrm{kg} / \mathrm{kWh})\end{array}$ & $\frac{\mathrm{NOx}}{(\mathrm{g} / \mathrm{kWh})}$ & $\begin{array}{c}\mathrm{PM} \\
(\mathrm{g} / \mathrm{kWh})\end{array}$ & $\begin{array}{c}\mathrm{SE} \\
(\mathrm{g} / \mathrm{kWh})\end{array}$ \\
\hline Base line & 32.2 & 17.7 & 211.16 & 720.20 & 0.23773 & 1.1802 & 0.019131 & 0.23236 \\
\hline Mexican Hat & 35.4 & 13.2 & 211.62 & 721.78 & 0.23721 & 1.2389 & 0.01479 & 0.22629 \\
\hline YaMZ & 29.3 & 17 & 211.19 & 720.32 & 0.23769 & 1.2943 & 0.014017 & 0.23163 \\
\hline ZMZ-514 & 31.5 & 15.9 & 211.23 & 720.43 & 0.23765 & 1.191 & 0.017952 & 0.22998 \\
\hline AVL- 528 & 33.1 & 16.3 & 211.06 & 719.87 & 0.23784 & 1.1885 & 0.018843 & 0.2326 \\
\hline
\end{tabular}

Table 6. Engine performance and emission comparison

\begin{tabular}{cccc}
\hline Performance & $\begin{array}{c}\text { Ford 6.7L V-8 } \\
\text { (Diesel No. 2) }\end{array}$ & $\begin{array}{c}\text { Optimized } \\
\text { (SME B20) }\end{array}$ & Difference \\
\hline Power $(\mathrm{kW})$ & 223 & 221.62 & $0.62 \%$ \\
Torque $(\mathrm{Nm})$ & 763 & 721 & $5.5 \%$ \\
SFC $(\mathrm{kg} / \mathrm{kW} . \mathrm{hr})$ & 0.2243 & 0.23721 & $1.3 \%$ \\
\hline
\end{tabular}

Finally, the comparison of engine performance and emissions for base line Ford $6.7 \mathrm{~L} \mathrm{V-8}$ engine and optimized engine are shown in Table 6. Ford $6.7 \mathrm{~L} \mathrm{V-8} \mathrm{engine} \mathrm{with} \mathrm{diesel} \mathrm{fuel}$ complies with Euro V emission standards [23] with $\mathrm{NO}_{\mathrm{x}}$ emission - 2.3g/kWh and $\mathrm{PM}$ emission - $0.015 \mathrm{~g} / \mathrm{kWh}$. By applying multiparametric optimization and using Mexican Hat piston bowl configuration, both $\mathrm{NO}_{\mathrm{x}}$ and $\mathrm{PM}$ emissions were reduced showing better results than those for Euro V standard.

Figure 10 shows the comparison of indicator pressures for reference fuel and optimized conditions with biodiesel blends. It can be seen that the pressure decreases with the use of biodiesel compared that of diesel. Among the biodiesel blends, pure SME biodiesel combustion showed the highest pressure rise, followed by SME B40 and then SME B20. Pure rapeseed methyl ester (RME) biodiesel showed the lowest in-cylinder pressure.

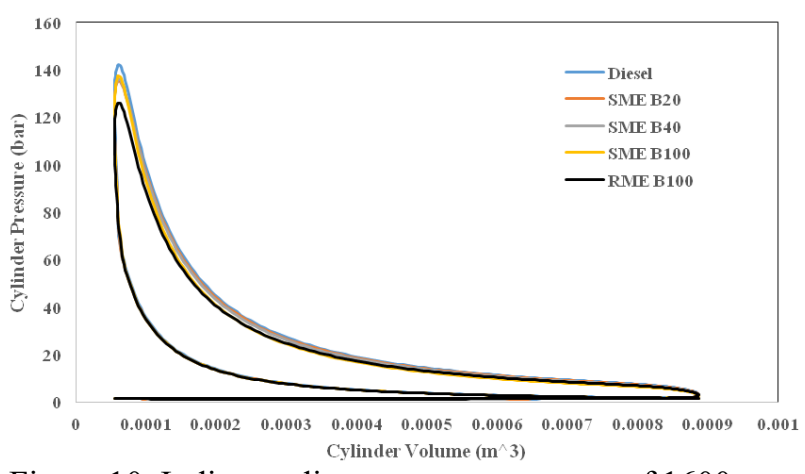

Figure 10. Indicator diagram at max. torque of $1600 \mathrm{rpm}$

\section{Conclusion}

From this study, the conclusions can be drawn as follows:

1. The increase of biodiesel percentage in the fuel blend causes higher specific fuel consumption.

2. Engine combustion with biodiesel fuel causes higher level of $\mathrm{NO}_{\mathrm{x}}$ emission compared to that of diesel fuel.

3. Multiparametric optimization of injection timing, injection duration and EGR rate allowed reducing $\mathrm{NO}_{\mathrm{x}}$ emission and 
summary emissions with slight increase in brake specific fuel consumption.

4. With increased exhaust gas recirculation rate, $\mathrm{NO}_{\mathrm{x}}$ emissions and summary emissions decreased $81.8 \%$ and $75.4 \%$ respectively.

5. With the applied multiparametric optimisation technique and piston bowl analysis, the engine exhaust gas emission characteristics were further improved with small sacrifice in the engine performance.

Combined multidimensional optimization and piston bowl analysis allowed improving engine emissions level beyond Euro V standards.

\section{References}

1. Özener O, Yüksek L, Ergenç A. T, Özkan M. (2014). Effects of soybean biodiesel on a DI diesel engine performance, emission and combustion characteristics. Fuel, $115,875-883$.

2. Celikten I, Koca A, Arslan M. A. (2010). Comparison of performance and emissions of diesel fuel, rapeseed and soybean oil methyl esters injected at different pressures. Renewable Energy, 35(4), 814-820.

3. Palash S. M, Kalam M. A, Masjuki H. H, Masum, B. M, Rizwanul Fattah I. M, Mofijur M. (2013). Impacts of biodiesel combustion on NOx emissions and their reduction approaches. Renewable and Sustainable Energy Reviews, 23, 473-490.

4. Paul G, Datta A, Mandal BK. (2014). An Experimental and Numerical Investigation of the Performance, Combustion and Emission Characteristics of a Diesel Engine fueled with Jatropha Biodiesel. Energy Procedia 54, 455467.

5. Datta A. \& Mandal B. (2016). Numerical investigation of the performance and emission parameters of a diesel engine fueled with diesel - biodiesel - methanol blends. J Mech Sci Technol 30, 1923-1929.

6. Mat Yasin MH, Mamat R, Yusop AF, Idris MN, Yusaf T, Rasul M, Najafi G. (2017). Study of a Diesel Engine Performance with Exhaust Gas Recirculation (EGR) System Fuelled with Palm Biodiesel. Energy Procedia 110, 26-31.

7. Datta A, Mandal BK. (2018). Numerical prediction of the performance, combustion and emission characteristics of a CI engine using different biodiesels. Clean Technologies and Environmental Policy 1-18.

8. Rajak U, Nashine P, Singh TS, Verma TN. (2018). Numerical investigation of performance, combustion and emission characteristics of various biofuels. Energy Conversion and Management 156, 235-252.

9. Kuleshov A. and Grekhov L. (2013). Multidimensional Optimization of DI Diesel Engine Process Using Multi-Zone Fuel Spray Combustion Model and Detailed Chemistry NOx Formation Model. SAE Technical Paper 2013-01-0882.

10. Kuleshov A. S. (2006). Use of MultiZone DI Diesel Spray Combustion Model for Simulation and Optimization of Performance and Emissions of Engines with Multiple Injection. SAE Paper No. 2006-01-1385.

11. Rosenbrock, H. H. (1960). An automatic method for finding the greatest or least value of a function. The Computer Journal, 3, 175-184.

12. POWERSTROKEHUB (2017). 6.7L POWER STROKE DIESEL. Retrieved from http://www.powerstrokehub.com/6.7-powerstroke.html.

13. Buyukkaya E. (2010). Effects of biodiesel on a DI diesel engine performance, emission and combustion characteristics. Fuel, 89, 3099-3105.

14. Chauhan B. S, Kumar N, Cho H. M. (2012). A study on the performance and emission of a diesel engine fueled with Jatropha biodiesel oil and its blends. Energy, 37(1),616622.

15. Godiganur S, Murthy C. S, Reddy R. P. (2010). Performance and emission characteristics of a Kirloskar HA394 diesel engine operated on fish oil methyl esters. Renewable Energy, 35(2), 355-359.

16. Nabi M. N, Rahman M. M, Akhter M. S. (2009). Biodiesel from cotton seed oil and its effect on engine performance and exhaust emissions. Applied Thermal Engineering, 29(11-12), 2265-2270.

17. Altun Ş, Öner C. (2009). Biodiesel production from inedible animal tallow and anexperimental investigation of its use as alternative fuel in a direct injection diesel engine. Applied Energy, 86(10), 2114-2120.

18. Xue J, Grift T. E, Hansen A. C. (2011). Effect of biodiesel on engine performances and 
emissions. Renewable and Sustainable Energy Reviews, 15(2), 1098-1116.

19. Mamat R, Ghazali W. N. M. W, Masjuki H. H, Najafi G. (2015). Effects of biodiesel from different feedstocks on engine performance and emissions: A review. Renewable and Sustainable Energy Reviews, 51, 585-602.

20. Borgelt S. C, Schumacher L. G, Fosseen D, Goetz W, Hires W. G. (1996). Heavyduty engine exhaust emission tests using methyl ester soybean oil/diesel fuel blends. Bioresource Technology, 57(1), 31-36.

21. Al-Dawody M. F, Bhatti S. K. (2013). Optimization strategies to reduce the biodiesel NOx effect in diesel engine with experimental verification. Energy Conversion and Management, 68, 96-104.

22. Kuleshov A. S. (2007). Multi-Zone DI Diesel Spray Combustion Model and its application for Matching the Injector Design with Piston Bowl Shape. SAE Paper 2007-011908. JSAE 20077057.

23. DieselNet (2017). Emission Standards. Retrieved from https://dieselnet.com/standards/eu/hd.php. 